\title{
EVERYDAY INTERACTIONS AND THE DOMESTICATION OF SOCIAL INEQUALITY
}

\author{
Elizabeth Keating
}

\begin{abstract}
This article examines the distribution of relationships of power and authority as an activity in gossip sessions among members of a community in Pohnpei, Micronesia. The position of Bourdieu, that the interactionist approach cannot elucidate important aspects of the sharing of power in society, is used as a starting place to examine ways in which interactants in everyday conversations manipulate and organize gendered identities and the entitlements of certain classes of individuals to particular types of power.
\end{abstract}

Keywords: Ethnomethodology, Social inequality, Gender, Gossip, Micronesia

\begin{abstract}
The 'interactionist' approach, which fails to go beyond the actions and reactions apprehended in their directly visible immediacy, is unable to discover that the different agents' linguistic strategies are strictly dependent on their positions in the structure of the distribution of linguistic capital, which can in turn be shown to depend, via the structure of chances of access to the educational system, on the structure of class relations. Hence interactionism can know nothing of the deep mechanisms which, through surface changes, tend to reproduce the structure of distinctive deviations and to maintain the profits accruing to those who possess a rare and therefore distinctive competence (Bourdieu 1994: 64-5, emphasis added).
\end{abstract}

\section{Introduction}

Bourdieu criticizes the "interactionist error which consists in reducing relations of power to relations of communication," and which therefore ignores the accumulation of symbolic power (Bourdieu 1994: 167). He criticizes the interactionist approach as unable to illuminate the process by which "distinctive deviations" (1994: 65) maintain inequalities. In this article I look at some aspects of the issue of where to focus efforts to understand the reproduction of social inequality. I am interested in examining the connection between communicative relations in a particular context and enduring power or the distribution of power in society. What aspects are missing in accounts of situated communicative interactions when we want to investigate the question of how one group dominates and 
"domesticates" ${ }^{1}$ another? This is a persistent and important question that critics pose to those of us studying situated interactions - whether such interactions can account for relationships between interactions (e.g. in a historical sense or in the memories of those present), including between interactants and between types of interactions.

There are means in every society through which resources are differentially distributed and certain members historically disadvantaged. These means are accounted for in talk and in stories which explain and naturalize social difference, and a close look at everyday interactions reveals there is much interactional space devoted to not only reproducing but contesting distinctive attributes of persons and groups, the power to make distinctions, as well as the meaning of symbolic media. Relations of domination are maintained by particular strategies that must be "endlessly renewed" (Bourdieu 1977: 183). Talk among community members can be a means of both contextualizing power relations within the boundaries of an event, and of decontextualizing such relations to transcend a single event through typification and atypification. Besides discussing these aspects, however, I am also interested in how a notion of 'enduring' power is itself an idea constructed and socialized in mundane interactions between people, where not only power relations but ideas about power are interactionally manipulated.

To Bourdieu, linguistics and anthropology make the mistake of appealing to context or situation to account for variation and exceptions, and by inference remain "locked within the framework of the rule and exception" (Bourdieu 1994). ${ }^{2}$ Practices have a relative autonomy with respect to external determinations of the immediate present, organized through the habitus, systems of "durable dispositions" (Bourdieu 1990: 53, see also Elias 1994 [1936]) which do not presuppose "a conscious aiming at ends or an express mastery" (Bourdieu 1990: 53) or attention to rules. On the other hand, to Garfinkel and ethnomethodologists, context or situation is crucial, not as a way to account for variations and exceptions, but in order to understand the procedures by which social actors hold each other accountable for variations and exceptions, or for commonalities of interpretation of candidate 'instances.' An actor's socialization, which for Bourdieu as with Parsons is the history through which s/he comes to unreflexive normative conformity, for Garfinkel is rather a history of the ways in which actors "are increasingly treated as aware of - and hence accountable" (Heritage 1984: 119, emphasis in original) in terms of playing certain language games or engaging in particular types of organization of the circumstances surrounding them. Actors to Garfinkel are thus continually engaged in a system of ad hoc behavior (Garfinkel 1967: 21) rather than "a spontaneity without consciousness or will" (Bourdieu 1990: 53). These theories situate responsibility for the reproduction of social life and social power quite differently. And they have different implications for change. In some ways the differences between these views, while sharing similarities, are somewhat like the differences between the stereotypical Hopi notion of time vs. the European. The Hopi see

${ }^{1}$ Bourdieu refers “in Weber's terms, to the “domestication of the dominated” (Bourdieu 1994: 167).

2 Bourdieu writes that practices cannot be deduced either from the present conditions which may seem to have provoked them or from the past conditions which have produced the habitus, the durable principle of their production. They can therefore only be accounted for by relating the social conditions in which the habitus that generated them was constituted, to the social conditions in which it is implemented, that is, through the scientific work of performing the interrelationship of these two states of the social world that the habitus performs, while concealing it, in and through practice (Bourdieu 1990: 56). 
time in terms of events, as event-like, or as another 'first time,' whereas the European sees time as objectified and spatialized. Is the nature of power as enduring a product of the way interactants talk about power? What does it mean if there is no "capital" only liabilities and accounts due, negotiated in and through particular contexts and relations?

The relationship between ethnomethodologists' work and other theoretical schools has been a focus of others working on situated talk (e.g. Wetherell 1998; McHoul 1988; Bogen and Lynch 1990; Lynch 1999; Titscher et all 2000). The question is often expressed as: Whether and how one can broaden a mandate of conversation analysis, expressed best by Schegloff, to consciously avoid "concerns extrinsic to the interaction unless of course it were possible to show the parties themselves oriented to these terms of analysis" (1998: 416). The exclusion of 'extrinsic concerns' was originally a conscious move to reject topdown theorizing by examining bottom-up interaction (Pollner 1991: 371). It was an attempt to reverse the "analytic move of subordinating language-use to prevailing ideological or institutional arrangements" (Bogen and Lynch 1990: 507). Some implications of this reversal, and the value of excluding from discussion aspects of social relations and identity that do not emerge in the actual stretch of talk examined, have been a topic of extended discussion in print (Schegloff 1998, 1999; Wetherell 1998; Billig 1999). An important part of the discussion is the role of indexicality. Speer has questioned the assumption that it is necessary to go beyond the text to understand the operation of identity work in society (2001). I am not arguing for limiting analysis to only what conversationalists make relevant, but rather I wish to address the question of whether and how "deep mechanisms" might emerge for analysis within everyday interactions in ways that are insufficiently recognized by those who criticize the ethnomethodological approach for its limitations and ingenuousness in terms of addressing questions such as social inequality. I am also interested in how ideas of the enduring nature of power emerge in interactions. I will discuss some everyday conversations I recorded during anthropological fieldwork in Micronesia. In these interactions, which might be called "gossiping," gendered behaviors and identities are symbolized and manipulated. At issue is the power of women, especially as it is related to sexual relationships.

Gossip is an activity where people often explicitly interpret the indexical properties of others' talk and conduct, as well as an area where distinctive deviations are constructed and discussed. Haviland (1977) has demonstrated how speakers recurrently manipulate cultural rules in the genre of gossip (see also Brenneis 1984 on the way gossipers build important relationships between themselves). Gossip and rumor play an important role in creating power and shaping reputations (Brison 1992; Briggs 1996; Bergmann 1993; Goodwin 1990). Gossipers engage in contextually-based accounts and accountabilities; they also construct an idea of pan-contextual, enduring relations including identities and power. In gossip, assessments (Goodwin and Goodwin 1987) organize common interpretations, including ethical (e.g. Besnier 1990) and aesthetic interpretations or judgments of value, and make the act of experience and interpretation an interactional event. The preferred or unmarked response to assessments in American conversation is agreement (agreement happens more swiftly than disagreement and usually without elaboration or accounts) (Pomerantz 1984; Schegloff 1968). Building agreed on interpretations is thus less complex than building disagreement about value (in sequential terms). While it can be argued that one of the failings of Speech Act Theory is that it does not fully account for the institutional authorization which underpins the efficacy of particular utterances (Bourdieu 1994), in the 
case of gossip, authorization is a mantle available to any who participate.

\section{Background}

The following examples of talk-in-interaction were collected in Pohnpei, Micronesia, a small society with a population of approximately 35,000 . The data were collected as part of a project to understand how particular grammatical forms are used to construct hierarchy in everyday interactions (see Keating 1998). Today Pohnpei is part of the Federated States of Micronesia, and a traditional chiefdom polity exists alongside a form of democratic, representative government (for a more complete description of Pohnpeian society see Riesenberg 1968; Keating 1998; Kihleng 1996; Mauricio 1993). Pohnpeians, like members of other societies, are continually negotiating relationships within different institutionalized authority systems, and are mediating new influences and signs through established and changing social values. The meaning of certain habits of bodies are negotiated in the gossip interactions discussed below in which interactants are engaged in construing a link between particular embodied performances and relationships to institutionalized roles, power and authority.

\section{Interactional distributions of power}

According to Bourdieu, part of the mechanics of the accumulation of (pan-contextual) symbolic power includes the process of identity construction: "The power of suggestion which is exerted through things and persons, which, instead of telling the child what he must do, tells him what he is, and thus leads him to become durably what he has to be, is the one condition for the effectiveness of all kinds of symbolic power that will subsequently be able to operate on a habitus predisposed to respond to them" (Bourdieu 1990: 55; emphasis added). In Bourdieu's ethnography, Kabyle women's bodies are habituated to orient downwards across contexts, whereas men orient up and out, for example. The body for Bourdieu is materialized in relatively constant meaningful forms, a rather permanent medium inscribed through childhood socialization procedures, almost an ideogram.

The interactants in the following excerpts are also concerned with theorizing the meaning of embodied actions and gendered identities and developing ideas of extracontextual power. In situated narrations of particular events, such as gossip sessions, each instance of behavior can serve as a contingent instance to be reasoned through. Talk is an important means of contextualizing power relations within the boundaries of an event, and of decontextualizing such relations through typification. The role of inconstant, disordered forms or atypical behavior is an important source in these interactions for the reproduction of the logic of identity, including gender and social distinctions. The interactants display accounts of other bodies in action, including clothing, posture, sexual activities, and discuss how to value these. They discover, create, and sustain standardization through actions (Garfinkel 1967: 66-7). 
These excerpts form a discussion about power and gender, ${ }^{3}$ stories through which behavior is symbolized and made meaningful. The typification, disciplining, and normalization of sexual invitations by women occurs here through situated tellings. Disorderly bodies or bodies showing initiative in the wrong contexts are acknowledged to have great power, a power which is nevertheless reframed as a kind of power whose accumulation should be thwarted and delegitimized. The way in which women's sexual power is contextualized and acontextualized contrasts significantly with the way male identity and power is constructed both in this narration and in narrations by men $^{4}$ (see also Eckert and McConnell-Genet 1995; Cameron 1997).

In the following excerpts, provocative body display is described as a powerful way to influence others' behavior, as uncivilized and indiscriminate power, as immature, as lifethreatening, as criminal and evil. All participants are married women with children. The women were spontaneously conversing while I was visiting them. One of them had recently returned from outside the island and was told about activities of others. Below, narrator A describes how M, a woman who already has a child of her own, is habitually enacting the "style" (an English loanword) of a small girl (kisin serepein) through her clothing, shorts rather than a skirt. Shorts are immodest in Pohnpei because of their revealing nature. The appropriate dress for women is clothing which conceals the natural shape of the culturally defined (and here redefined) erotic parts of her body, the area between the waist and the knee.

$1 \mathrm{~A}: \quad$ e kin wiala style duwete kisin serepein

'she habitually comports herself in a style just like a little girl'

2 A udahn soahng me sehten kisin rausis (...)

'really, with the same kind of shirt and shorts' (...)

Even when $\mathrm{M}$ wears the appropriate skirt, she chooses a sheer fabric (menipinip me aramas kileng weite 'thin that people can see into') which shows the outline of her thighs anyway. The narrator relates how she challenged M by saying, "are you even wearing a skirt?"

$1 \mathrm{~A}: \quad$ i pirekek kilang a likou tangete wasahn

'I turned around and saw her clothes were like this'

2 ((she asks $M)):$ “M ((name)), ke urohs?"

${ }^{3}$ See also Kotthoff and Wodak 1997 for discussions of gender and context.

${ }^{4}$ See also Eckert and McConnell-Ginet 1995 for a discussion of high school girls and boys in one segment of American society. 
"M, are you even wearing a skirt?"

3 eri mwahu men re aramas kileng weite dahngemwen 'you think it's good if people can see your thighs?'

4 dah ke kin koasongosongih ohlakan"

'what are you doing always enticing men?"'

It is not simply a matter of choice of dress, but rather how this choice of dress is linked to other behavior which links the present instance to institutionalized values and hierarchies. Women's sexual modesty and its correlation with female identity or respectable femininity has been described in other societies (e.g. Abu-Lughod 1986). Women's overt sexuality is often interpreted as a threat to the social order, and virtue is equated with limiting this power to certain domains. ${ }^{5}$ In a move to undermine the legitimacy of women's sexual power and to suggest the atypicality of this female behavior, the narrator asks, "what kind of woman is that?"

$5 \quad$ Dah songen lidep

'what kind of woman is that (who has already has a child)' (...)

$6 \quad$ iapw sohte mwahuki. urohs me udahn

'but I don't like it. That kind of skirt is really thin'

$7 \quad$ menipinip me aramas kileng weite kilang

'and people can see through it, can see'

8 ah sarmada tengie. Kilang wanded

'where her underwear goes. That looks like a "wanted" woman'

The use of the word wanded in line 8 introduces, in addition to the categorical question of identity mentioned above, the issue of criminality and discipline. 'Wanted' is an English word borrowed by Pohnpeian women from the "Wanted" posters common in United States post offices, posters that are now familiar to Pohnpeians, who have one post office managed by the U.S. Postal Service as a holdover from the American colonial or postwar Trust Territory period (1947-83). U.S. "Wanted" posters have a picture of a criminal who has escaped and is now wanted by the state penal system. The term wanded is applied by Pohnpeian women to women who are sexually promiscuous (and in fact has become a synonym for female promiscuity). There are some interesting contrasts, similarities, and opportunities for analogies in the way breaches are constructed both within the context of

5 "To achieve virtue, those most disadvantaged by the social system must suppress in themselves that which threatens the social system, especially in front of those who represent and who have the most to gain in the system" (Abu-Lughod 1986: 152). 
U.S. wanted posters and in the context of wanded in Pohnpei. By analogy, the women institutionalize particular portraits of deviance, and construct the "criminal" women as fugitives as well as deviants. The term also plays on the double meaning of "wanted," sexual desirability and dangerous social disruptors, who are at-large.

In addition to being labeled 'wanted,' $M$ is called Satan by another participant in the interaction. W quotes herself as saying to a man, "look at the Satan there" referring to M. $\mathrm{M}$ is linked to one of the most powerful forces in Christianity described through histories and sacred texts, representing expulsion from a community with high moral values, as well as ever-present temptation. The use of the labels 'wanted' and 'Satan' for the woman indexes not only a certain foreignness but relates local, interactionally produced formulations of deviance and power to established institutions.

$1 \mathrm{~W}$ : ih indang $J$ (name) kilang sedane me 'I told J (name) "Look at the Satan there",

\section{L: $\quad$ ke ese sohte mehkot mwahu}

'you know there's something there that's not good'

3 pwakiala sang me, pwe kakadongadong

'chase her away from here because she makes herself abhorrent'

The woman, according to L, should be chased away (pwakiala sang me "chase away from here') because she "makes herself abhorrent" (kadongadong)." $\mathrm{M}$ is responsible for the negative reaction towards her of people around her. These types of women karkarkadongidongih aramas or 'cause people [i.e. not only women] to hate them'.

In the same interaction, another woman is discussed. This woman has been given the nickname Pazuka by her husband (after bazooka, a type of weapon). The narrator quotes herself asking the husband of the woman the meaning of the name he has given her and reports the husband as saying: "I gave her that (nick)name because, you know that kind of gun is really powerful. It will habitually just pound something to pieces" (lines 8-9). He characterizes as entirely destructive women's unconstrained sexuality.

(the narrator's husband asks the man):

7 "nahn ia wewehki omw kieng eden B (name), Pasuka?"

"'friend, what's the meaning of this name you gave B (name), Pasuka?"

$8 \quad$ "i kieng ede pweke ese soahngen

"II gave her that name because you know that kind of'

9 kesik me udahn kelailo. me pahn kin posete lelete mehkot kesepeseng 'gun is really powerful. It will habitually just pound something to pieces', 
11 a kin mwomwen mwehlki in tapio mwo 'she was sad to have that name at first'

Being called a weapon of destruction made the woman unhappy (line 13). W expresses sympathy, an understanding of the power of sexual desire for some people (line 2). This sentiment is answered by the narrator, U, who says 'yes, maybe', and a third participant, $S$, challenges this more sympathetic portrayal: The proper context for such behavior is her spouse.

(6)

$1 \mathrm{~W}$ : wehwehki ineng koaros e kin wia ansou

'one understands all the sexual feelings she has at times'

$2 \mathrm{~A}: \quad$ ehng mwein

'yes maybe'

$3 \mathrm{~S}: \quad$ e sou kohla kadoakih ah pwoudo?

'she can't have sex with her husband?'

Age inappropriate sexual behavior is also a misuse of power, and is ridiculous. A woman is criticized for allowing teenaged boys 'to do' things to her (wiwiaieng), or play with her. This woman also wears immodest clothing: "only a small skirt and no top or shirt" (kisin uroste dop sohte pil seht). The children are "laughing heartily at her" (ira ngarngarak). Female sexual desire is alternately resymbolized from dominating to dominated in this story.

The use of 'dog' (kidi) for inappropriate sexual relations is often used in Pohnpei. Here it is employed by one participant: Udahn kidi douluhl "really (she's a) dog truly." This is similar to the use of the word 'bitch' in English, though in English 'bitch' has a more generalized meaning of aggression or assertion of power by women. In Pohnpei the analogy is to the wild or unreflexive sexual behavior of only partially domesticated animals who are part of the everyday scene in Pohnpei. Certain linguistic devices are used by both men and women to typify women's sexual misbehaviors - dog-like, gun-like, girl-like; all are outside the category 'woman.' The discourse constructs a particular type of adult female body as negative, disruptive, incongruous, and less than human.

Other gendered power distributions emerge in this interaction. The activity of women criticizing other women's bodily presentation and sexual behavior is classed by a man as usurping power profanely. The authority and power of the women gossipers is undermined by the voice of the husband of one participant (see excerpt 7). The wife herself brings his voice into the discussion. She reports that her husband, R, said she will be cursed, riahla, for "criticizing others" (lines 1-2) when she assesses others' "style." Such a curse, riahla, comes from breaking a tabu, and results in disease or misfortune. Riahla as a punishing force historically predates the Wanted posters. It can be visibly manifested on 
the body as skin lesions and other forms of rupture.

1 A: $\quad$ ah $R$ (name) inda dene kilang pwe ke pahn riahla 'but R says they say "look because you will be cursed" (for gossiping)'

$2 \quad$ (narrator animating R's voice) “kowe mwahuki kawe aramas "'you always criticize people'

3 menda remw kin pil indinda songen style in emen" 'never mind your habitual talking about some people's style"'

Gossipers here and elsewhere, especially female gossipers, are often alleged by others to be as deviant or more deviant than their subjects of gossip, delegitimating a source of female power and situating the illegitimacy of women's power within the genre itself. However, A sarcastically alludes to the fact that showing the outline of one's buttocks hardly qualifies as style (lines 5-6), and she deflects her husband's criticism of her own authority.

$4 \mathrm{~A}: \quad M$ (name) ah likouo tangete nan kahwen udahn kin style

$\mathrm{M}$, her clothes run in her buttocks crack that's really stylish!

At the same time, the women's power to narratively discipline other female bodies conceals, as Foucault has shown, that it is also the disciplined body that subverts the sovereignty or authority of women. The voice of the male here, even as it argues against women's power to judge, argues for the behavioral autonomy of women.

In the next excerpt (a different conversation in a different part of the island) a woman relates how she would like to change her bodily presentation, e.g. wear shorts like American women, but she relates to her friend and me in this conversation that her son told her if she does, he will quit school from shame before his peers (lines 5-6).

1 S: $\quad M K$ (S's so) kahng ien iang wia songen. I kin men

'MK refuses (forbids) my doing that kind of thing. I always want to'

2 iang wia songko MK kapweiekala

'join that type of behavior. MK (her son) doesn't want me to'

3 pweki mweliki pwe kilang ehu rahno

'because it would make him sad because one day we saw'

$4 \quad$ lepin rausis $i$ inda mai pahn pwainda 
'shorts, I said I'm going to buy some'

ai lepen rausis e kahng kalakalekete "ke dehr pah

'shorts for myself and he refused me, "just don't you dare'

6

lepin rausis kohla ihmwen skulo. Ke pahn kareda i sohla iang skul"

'don't wear shorts and go to my school. You will make me quit school"'

This particular woman's son is concerned that she would identify herself through clothing as immoral, uncivilized, and dangerous.

Conversationalists link ideas about identity and power relationships to particular past events and to people. ${ }^{6}$ Disorderly bodies can be a meaningful source for the reproduction of ideas about power, linking contexts through time and space. Typification is built in gossiping events by reasoning through instances of appearances of its opposite, atypification. For example, an account of promiscuity can serve as a contingent instance of the distribution and use of power to be reasoned through. The idea of the enduring nature of power relationships is at least partly built through talk, categorizing social relations through typification and the appeal to institutionalized categories, as well as the organization of events to create coherence out of contradiction.

\section{Conclusion}

Bourdieu criticizes "subjectivism," or the goal of trying to understand the way the world appears to the individuals who are situated in it (Thompson 1994: 11). To Bourdieu the social world is not reducible to the practical knowledge demonstrated by lay actors, but rather actors are unaware of key aspects of the effects of their unconscious habits, for example, how through habitus they are unwitting participants in their own subjugation ${ }^{7}$. The habitus, a "durably installed generative principle of regulated improvisations" seems not unlike language, learned in the first years of life, an arbitrary set of symbols that "tends to appear natural." As Sapir wrote: "Languages are...invisible garments that drape themselves about our spirit and give a predetermined form to all its symbolic expressions" (1921: 221). Habitus at times sounds Sapir-Whorfian (cf. Hanks 1996). However, members of societies do constant work to maintain some of the arbitrary and shifting connections between signifier and signified. It is this work that linguistic anthropologists are interested in.

Bourdieu refers "in Weber's terms, to the "domestication of the dominated"" (Bourdieu 1994: 167) through the unequal distribution of power due to class relations. This act of domestication is alternately viewed in Garfinkel's terms as a product of interactions

\footnotetext{
${ }^{6}$ In Speer's study men discussing masculinity shape and reshape their ideas of how they understand the category of masculine according to context and audience (Speer 2001).

${ }^{7}$ As an example, Bourdieu uses the work of Labov (e.g. 1972) and the silent violence in stigmatized attitudes toward postvocalic "r" even by those who use it.(Bourdieu 1994: 52).
} 
where we 'normatively' account for the actions of others: "Normative accountability can best be viewed as organizing, channelling and, in a sense, 'domesticating' the ways in which interests may be realized" (Heritage 1984: 116-117). Conversationalists create local ideas not only about conformity and nonconformity and important distinctions in terms of legitimate power relations, but they create ideas about the durability of cultural forms, including power relationships. Studying everyday conversations in certain contexts can show how language used in the "directly visible immediacy" (Bourdieu 1994: 64-5) is an important tool in the complex machinery of social difference and dominance, and such conversations can provide data for better understanding the widespread process in human societies of socially disadvantaging some groups over others. ${ }^{8}$

\section{References}

Abu-Lughod, Lila (1986) Veiled sentiments. Berkeley: University of California Press.

Bergmann, J. (1993) Discrete indiscretions. The social organization of gossip. $\quad$ New York: Aldine / de Gruyter.

Besnier, Niko (1990) Conflict management, gossip and affective meaning on Nukulaelae. In K. WatsonGegeo, and G. White (eds.), Disentangling: Conflict discourse in the Pacific. Stanford, CA: Stanford University Press, pp. 290-334.

Billig, Michael (1999) Whose terms? Whose ordinariness? Rhetoric and ideology in conversation analysis. Discourse and society 1999 10.4: 543-558.

Bogen, David, and Michael Lynch (1990) Social critique and the logic of description. Journal of Pragmatics 14: 505-521.

Bourdieu, Pierre (1977) Outline of a theory of practice. Cambridge: Cambridge University Press.

Bourdieu, Pierre (1990) The logic of practice. Richard Nice trans. Stanford: Stanford University Press.

Bourdieu, Pierre (1994) Language and symbolic power. Harvard: Harvard University Press.

Briggs, Charles (1996) Disorderly discourse: Narrative, conflict, and social inequality. Oxford: Oxford University Press.

Brison, Karen (1992) Just talk. Berkeley: University of California Press.

Brenneis, Donald (1984) Grog and gossip in Bhatgaon: Style and substance in Fiji Indian conversation. American Ethnologist 11: 3.

Briggs, Charles (ed.) (1996) Disorderly discourse: Narrative, conflict, and social inequality. Oxford: Oxford University Press.

${ }^{8}$ Acknowledgements. This paper is a revised version of a paper presented at the invited session Embodying Linguistic Ideologies (organized by Jim Wilce) at the American Anthropological Association Annual Meetings in 1998. My thanks to Jim and to Bill Hanks, a discussant for the session, for many helpful and insightful comments. 
Cameron, D. (1997) Performing gender identity: Young men's talk and the construction of heterosexual masculinity. In Sally Johnson, and Ulrike Meinhof (eds.), Language and masculinity. Oxford: Blackwell.

Elias, N. (1994) [1939] The Civilizing process. Oxford: Blackwell.

Eckert, P., and S. McConnell-Ginet (1995) Constructing meaning, constructing selves. In K. Hall, and M. Bucholz (eds.), Gender Articulated. New York: Routledge.

Garfinkel, Harold (1967) Studies in ethnomethodology. Englewood Cliffs, NJ: Prentice Hall.

Goodwin, Marjorie (1990) He-said-she-said: Talk as social organization among black children. Bloomington: Indiana University Press.

Goodwin, Charles, and Marjorie Goodwin (1987) Concurrent operations on talk: Notes on the interactive organization of assessments. IprA Papers in Pragmatics 1.1: 1-52.

Hanks, William F. (1996) Language and communicative practices. Boulder, CO: Westview Press.

Haviland, John (1977) Gossip, reputation, and knowledge in Zinacantan . Chicago: University of Chicago Press.

Heritage, John (1984) Garfinkel and ethnomethodology. Cambridge: Polity Press.

Jenkins, Richard (1992) Pierre Bourdieu. New York: Routledge.

Keating, Elizabeth (1998) Power sharing: Language, rank, gender and social space in Pohnpei, Micronesia. New York: Oxford University Press.

Kihleng, Kimberly (1996) Women in exchange: Negotiated relations, practice, and the constitution of female power in processes of cultural reproduction and change in Pohnpei, Micronesia. Ph.D. Dissertation, University of Hawaii. (UMI No. 9700526)

Kotthoff, Helga, \& R. Wodak (eds.) (1997) Communicating gender in context. Amsterdam: Benjamins Publishing Company.

Labov, William (1972) Language in the inner city: Studies in the Black English vernacular. Philadelphia: University of Pennsylvania Press.

Lynch, Michael (1999) Silence in context: Ethnomethodology and social theory. Human Studies 22: 211-233.

Mauricio, Rufino (1993) Ideological bases for power and leadership on Pohnpei, Micronesia: Perspectives from Archaeology and Oral History. Unpublished Ph.D. dissertation, University of Oregon (UMI\# 9402036).

McHoul, Alec (1988) Language and the sociology of mind: A critical introduction to the work of Jeff Coulter. Journal of Pragmatics 12: 339-386.

Pollner, Melvin (1991) Left of ethnomethodology: The rise and decline of radical reflexivity. American Sociological Review 56: 370-380.

Pomerantz, Anita (1984) Agreeing and disagreeing with assessments: Some features of preferred/dispreferred turn shapes. In J. Maxwell Atkinson, and John Heritage (eds.), Structures of social action: Studies in conversation analysis. Cambridge: Cambridge University Press, pp. 57-101. 
Reisenberg, Saul (1968) The native polity of Ponape. Vol 10 of the Smithsonian Contributions to Anthropology. Washington, D.C.: Smithsonian Institution Press.

Sapir, Edward (1921) Language: An introduction to the study of speech. New York: Harcourt, Brace, Janovich.

Schegloff, Emanuel (1968) Sequencing in conversational openings. American Anthropologist 70: 1075-95.

Schegloff, Emanuel (1998) Reply to Wetherell. Discourse and Society 9.3: 413-416.

Schegloff, Emanuel (1999) Naivete vs sophistication or discipline vs self-indulgence: A rejoinder to Billig. Discourse and Society 10.4: 577-582.

Speer, Susan (2001) Reconsidering the concept of hegemonic masculinity: Discursive psychology, conversation analysis and participants' orientations. Feminism and Psychology 11.1: 107-135.

Thompson, John (ed.) (1994) Editor's introduction. In Pierre Bourdieu Language and symbolic power. Cambridge: Harvard University Press.

Titscher, S., M. Meyer, R. Wodak, \& R. Vetter (2000) Methods of text and discourse analysis. Translated by B. Jenner. London: Sage.

Wetherell, Margaret (1998) Positioning and interpretive repertoires: Conversation analysis and poststructuralism in dialogue. Discourse and Society 9.3: 387-412. 